\title{
Learning Construction of Students of Prospective Teacher Based on Digital Literacy in the Era of Pandemic Covid-19
}

\author{
$\mathrm{Umar}^{1}$, Ismail $^{2}$ \\ \{oemar.tech.iaim@gmail.com ${ }^{1}$ \} \\ Tarbiyah and Teacher Training, Islamic Institut of Muhammadiyah Sinjai, 92611, Indonesia ${ }^{1,2}$
}

\begin{abstract}
This article aims at building literacy-based learning for students of prospective teacher. Empirical problems sound that the effect of Covid-19 pandemic has affected education in various countries, including Indonesia. As a result, learning interactions are reduced due to a limited movement and access to learning, parental support, and significant changes in the new normal era, while conditions require life skills. This requires students of prospective teacher to have digital literacy skill as the competence of 21 st century. It is very important to pay attention to them through integrative and adaptive learning constructs. There are various suggestions for studying in the era of pandemics. Qualitative methods focus on learning case strategies, students of prospective teacher, and lecturer to participate in this study. The data were collected and analyzed. Students of prospective teacher are digital media users in learning activities, while digital literacy skills demonstrate personal and social competencies and interventions from internal and external circumstances. Learning construction should pay attention to adaptive, participatory, integrative action, guidance, example, friendliness, and control of humanist movements. It is expected to improve professionalism and encourage the success of future prospective teachers in their profession.
\end{abstract}

Keywords: Learning construction, student-teacher candidates, digital literacy.

\section{Introduction}

The era of the industrial revolution 4.0 has been marked by the digitalization of various fields, especially education. Meanwhile, the vision of 21st century education requires the younger generation to able to contribute on global level. Meanwhile, the Covid-19 Pandemic has disrupted the education sector for 9 (nine) months, resulting in significant structure and learning patterns. The Indonesian government has set an emergency policy so that learning adapts to the digital-based learning environment due to social limitations and physical distance; thus, teachers and students must learn and master digital media online. However, in fact various online learning problems have been arisen.

The extension of the distance learning period is contained in a circular letter from the Ministry of Religion of the Republic of Indonesia, Ministry of National Education, PP Muhammadiyah Diktilitbang Council, Governor of South Sulawesi Province, Regent of Sinjai, and Rector of IAIM on the importance of online learning during the Covid-19 Pandemic. Meanwhile, the records of the Database and Bureau of IAIM Sinjai in the even academic year 2019-2020 and odd 2020-2021, indicates that students of prospective teacher of the Faculty of 
Tarbiyah and Teacher Training have been involved in a distance learning. However, there are barriers such as internet networking, effectiveness and learning outcomes, organizing scientific assignments, presenting ideas, analyzing information content, and understanding scientific terms. This indicates that students' digital literacy skills are still low. However, the fact is that digital devices use is classified as massive among students and university students. The wide range of uses of information services, social media, games, and entertainment should improve literacy skills. Studies have shown that that teachers' familiarity with digital media does not guarantee teachers' competence in functional and pedagogical digital-based classroom learning $[1]$.

In contrast, the intensity of smartphone use has a significant influence towards communication behavior but has a negative impact on users [2]. Attention tends be unproductive matters and is unable to use technology in writing scientific papers accurately [3]. Students' perceptions during online learning are constraints on digital facilities, networks, and support devices [4]. Many colleges have difficulty establishing an online infrastructure, which hinders learning effectiveness [5]. This is because teachers do not understand the essence of online learning, and student's lack of freedom to learn [6]. Factors of ownership influence the gap in students' digital literacy skills, communication costs, and age initially using ICT [7].

The college student paradigm on online-based learning tends to be burdensome and does not accommodate learning interest. As a result, learning only accommodates teachers in completing teaching assignments, and participants are less successful. The Ministry of Education and Culture in 2017 has intensified the National Literacy Movement as part of the implementation of Permendikbud No. 23 of 2015 [8]. This movement target includes literacy culture in family, school, and wider community education. The educational ecosystem plays an important role in activating students' literacy culture, including in higher education. Meanwhile, the World Economic Forum 2015 determined six basic literacies, such as literacy, numeracy, science, finance, culture, citizenship, and digital literacy to develop 21 st century life skills.

Thus, integrative learning based on digital literacy can be an alternative through pedagogical and constructive approaches. Since the students of prospective teacher are "digital natives" born from 2000 to 2010, they have personal way of acquiring knowledge through digital. Studies show that digital understanding of literacy has psychological effects on children and adolescents [9]. Meanwhile, digital literacy learning teachers in early childhood classes have offered digital resources that promote literacy learning for playing, scaffolding, and exploration [10]. The Final Report on the Assessment Criteria for the Level of Media Literacy in 2009 by the European Commission proposed the concept of determining the competence of individual competencies in digital literacy, such as using and utilizing, producing, analyzing, and delivering messages through the media [11].

Prospective teachers need to be equipped with adequate digital literacy skills as future learning interactions become increasingly complex and competitive. This means the demand to prepare prospective teachers' professional identity is ready to be competitive because learning has been integrated with technology [12]. The practice of digital literacy essentially forms creative, innovative, and contemporary education [13], [14] to demonstrate successful performance and achieve better learning outcomes [15]. Students with digital literacy skills will evaluate and use technology critically, information, and communication [16], become skilled digital citizens by adopting critical, multi-capital, and interdisciplinary pedagogical approaches [17].

Also, there is a paradigm shift in society if the teaching profession promises future success [18]. Therefore, the widespread use of digital media for students of prospective teachers should enhance literacy skills further. This study aims at determining the implementation of online 
learning based on digital media during the Covid-19 pandemic, the digital literacy skills of prospective teacher teachers, factors influencing digital literacy skills, and building student learning through digital media literacy.

\section{Method}

This study utilized a qualitative type case approach, which considered and tried to constructively comprehend the learning cases of students of prospective teachers during Covid19 Pandemic. The subjects of study were lecturers and students of prospective teacher of Faculty of Tarbiyah and Teacher's Training of IAIM Sinjai in the odd academic year 2019-2020 and 2020-2021 by considering the purposive sampling. The criteria of participant criteria were the subjects' heterogeneity comes from the Bugis and Khonjo tribes and languages with different dialects. The majority of subjects live in Sinjai and Bones hinterland with a moderate economy family background. Data collection utilized various techniques, such as offline and online learning observations (Zoom, Google Meet, and WhatsApp), interview with lecturers, and students of prospective teacher. There were 12 lecturers (PD) and 12 students who participated (PM), in addition to using audiovisual recordings [19], [20]. Researchers equip themselves with observation and interview instruments. The validity of the discovery data has taken into account the measures of credibility (presenting the data and proving it in twice), transferability (describing the data), reliability (repetition of the study), and validation (conveying the results to the informants). Data analysis using conditional, conditional, exposure and validation / conclusion models [21].

\section{Results and Discussion}

\subsection{Overview of Digital-Based Online Learning}

Digital-based online learning for students of prospective teachers takes several forms; (1). YouTube media in "Research Methodology" course of Islamic Religious Education Study Program, Teacher Education Madrasah Ibtidaiyah, and English Language Education utilized by Mr. Ismail. Meanwhile, Mr. Danial applied "Algebra" lesson to the Mathematics Education Studies Program. Lecturers create video content material, which is uploaded on the YouTube channel and accessed by the students for learning. (2). Google Class Media utilized by Mrs. Harmilawati on learning "Basic English Structure" in the English Education program. "Bahasa Indonesia" lesson utilized by Mrs. Laeli Qadrianti in the Islamic Religious Education and Arabic Language Education program. Students attend lectures by attending classes according to the code given by the lecturer. Completion of assignments in the form of paper and power points. (3). Media Zoom Meet and Google Meet utilized by Mr. Muhammad Kadir to teach "Diagnostic Learning Difficulty" in the Madrasah Ibtidaiyah Teacher Education program. Students attend those lectures and have face-to-face discussions after receiving the lecturer ID. (4). WhatsApp media group utilized by Mrs. Hasmiati teaches "Educational Management," "Basic Teaching Skills," "Kemuhammadiyahan Al-Islam" in the Madrasah Ibtidaiyah Teacher Education Study Program, Islamic Religious Education and Tadris Mathematics. Lecturers distribute assignments through groups, and student's complete lecturer assignments. (5) Microsoft 365 Media utilized by Mrs. Irmayanti and Mrs. Nurjannah teach "Educational Statistics" in the 
Mathematics Education Study Program. Each lecturer teaches materials using a variety of applications according to student preferences.

\subsection{Digital Literacy Skills of Students of Prospective Teacher Personal Competencies (Technical Skills and Critical Understanding)}

Lecturers and students of prospective teacher delivers argument that smartphones, tablets, and notebooks are used as personal communication media and social information sources. Also, as a medium to find references for lecture assignments. "The majority of students use digital media instead of manuals. Their interactions use social media; many of them great at designing, accessing quality reference sources. However, in learning, the practice of copying and pasting is still commonplace" (PD-2). We currently use smartphone media in learning because of pandemics, and not all of them support skills, as they are used more for communication" (PM9).

This phenomenon shows that digital media has contributed to learning, such as learning and social media. Immediate service can be a factor of dependence on digital media. Meanwhile, digital literacy and information analysis do not present it as an act of learning, ability, and critical understanding. This situation causes passive learning such as presentation and class discussion; lecturers and students dominate learning are not involved as discussion partners. The digital literacy figure of students of prospective teacher demonstrates technical and cognitive skill by operating digital devices and interaction with computers, smartphones, and the internet in learning and beyond learning activities. In other words, students know, identify, and use digital media functionally and effectively.

\subsection{Social Competence (Communicative Ability)}

Besides, students of prospective teachers have interactive communication skills and build relationships, such as using social media services via smartphone devices with Whatsaap media services, Google Meet, Google Classroom, and while studying with lecturers. "Generally, social media such as WhatsApp, Facebook prefer to be used for communication between friends, family, and others. There are very few participants who are interested in learning the subject through groups, because there is no reading interest and motivation" (PM-1). "We generally complete the learning task by referring to the internet, as well as the interactive social media used to discuss when lecturers do not have time to teach" (PM-2).

Social competence can be seen through digital tools, especially interactive social media services, surfing the internet to obtain information resources, and online games, both individually and community-based (group). Such activities have demonstrated the ability to communicate and form a broad academic and social network (the ability to collaborate). Producing information content (content creation) is still under control, such as analyzing, presenting oral and written language in a constructive descriptive manner. The results show that digital media learning skills are generally unequal because students have problems using google classroom and searching for indexed journals. Different abilities are due to independent initiative and low learning interest.

\subsection{Factors Influencing Digital Literacy Skills Supporting Factors}

Students of prospective teachers see their digital literacy skills supported by "good internet network factor" (PM-3). "Adequate performance of digital devices and internet quotas" (PM- 
4). "Library book availability and learning" (PM-5). "Advanced digital features for longdistance communication, information, and news" (PM-6). The statements indicated that adequate support facilities and digital media devices can enhance digital literacy skills. Also, "parents do not miss information from various media, so we are also motivated to learn and improve our abilities" (PM-7). "Almost everyone around me uses digital media for information needs nowadays, so we are also expanding ourselves" (PM-8).

This shows an environmental support, personal habits, and social interactions. Parents' role in family life has created a comfortable learning environment, provided role models and adaptations so that the use of digital tools on a large scale is considered as a major need in learning. On the other side, factors of users' habituation, social interaction, and communication culture become the supporting factors of literacy skills. The respondents stated, "Learning independence, interaction between students and lecturer should be considered because culture and communication independence will habituate and develop digital literacy skill” (PD-3).

\subsection{Inhibiting Factors}

Barriers to digital literacy for students of prospective teachers are internal and external factors such as low human resources and interest in learning, cost and digital means, and learning environment. "Knowledge and skills are still low"(PM-9), "it is difficult to understand quality references using foreign languages" (PM-6), "tired of operating digital equipment if the device is often damaged" (PM-11), "poor quality of Wi-Fi and internet network" (PM-10), "inadequate and high-cost internet facilities in the village" (PM-5), and "limited subject books" (PM-7). Furthermore, respondents if students' digital literacy skills are not getting educational support. "We are still trying to take practical steps to teach internet and digital media skills, usually before teaching lecturers at the beginning of the semester lectures only deliver technical writing articles and refer honestly, but rarely teach the importance of analyzing information" (PD-1). "Many untrustworthy websites are used as a reference for information and writing assignments because we are rarely given the right methods and many more interesting game applications" (PM-12). "Students have dependence, for example, only relying on the internet when the percentage" (PD-3).

\subsection{Students Learning Constructions Based on Digital Media Literacy}

The interview observations and statements indicated a constructive learning strategy for prospective teacher of digital-based students, such as; (1). Adaptation and participation strategies. Adjust the learning tools used collectively prior to the learning. Lecturers provide media and learning resources such as relevant textbooks and online media platforms to learn independently and attach teaching training and provides online assessment services. Indonesian government program support in providing internet quotas, and students submit phone numbers to get free internet. (2). Guidance strategies and learning habits. Lecturers have been involved as role models, motivators, and rewarders, fostering a comprehensive reading of literature from a variety of sources, sharing reliable and scholarly reading materials, helping to provide information services that stimulate active and independent learning abilities, critical thinking, analysis, and synthesis of developed symptoms. "Directs them to tend to read journals online, especially this semester, so that they can get used to it" (PD-2). "Provide learning support resources such as e-books and links to find open access towards e-journals in lectures" (PD-1). (3). Control strategies. Manage discipline and self-management during online learning, mutual 
control agreement, use digital media for communication (social media), entertainment and learning, and provide examples of friendly behavior and ongoing assessment.

This study found that student learning constructs based on prospective teachers' digital literacy have maintained a theoretical basis. The implementation of online learning has been in line with the current government and institutional policies of the Covid-19 Pandemic. Teachers conducted learning based on mutual agreement by using different platforms such as Zoom, Google Meet, Google Classroom, WhatsApp social media, Facebook, and YouTube that take into account the abilities of learning participants. It supports previous findings that teachers generally have used online learning interactive media, but the weakness is there has not been found teacher evaluation regarding the use of media platforms [22]. Other findings show that Indonesia has provided good online infrastructure, but teachers do not understand the essence of online learning, and students lack the freedom to learn [6].

Platform choices have considered theoretical learning materials using Zoom, Google Meet online, while practical learning tends to be through YouTube videos. This is in line with previous studies' results if distance learning based on social media is effective for theoretical courses and less effective in practical learning [5]. Therefore, it is important to pay attention to the principles of relevance and meaning, such as effective delivery, adequate support, high participation, and possible planning arrangements [23]. In the basic digital literacy level, student on basic level of digital literacy can implement learning resources, educational sites, and online learning applications [24]. Even early childhood learning offers digital resources that promote literacy in games, scaffolding, and exploration [10], including how to provide information to generation Z [25] effectively. The challenge of using this method is to identify children's participation in learning that requires adult help. Requires critical and constructive analysis skills to understand information. Independent learning and school policies do not accustom students to use digital media devices.

Cultivating digital literacy skills has considered adaptive learning with student-teacher candidates in Indonesia. Instead, countries like India [22], China [26], and South Korea have adaptive digital media relevant to distance learning. These findings also perpetuate theoretical concepts if the participants' abilities are characterized by personal and social aptitude [11]. Personal competence only shows a part of technical proficiency and does not apply in critical understanding because of the lack of free learning. Meanwhile, social agility only proves the ability to foster social relationships based on digital media and does not promote and produce media content.

Digital literacy skills can be developed if there is free learning factor in individuals carried out meaningfully. Previous studies have suggested the importance of integrating and implementing meaningful learning because it will strengthen digital pedagogy, self-confidence, skills, and professional teachers of the future [27]. Also, other factors indicate the use of "groups/communities" based on digital media and social media to develop literacy skills to provide contribution towards learning and form a solid learning community. Every internal and external situation has affected digital literacy skills; this is important to get individuals and interested parties' attention.

Digital media literacy in students of prospective teacher is crucial and urgent to consider. It requires unlimited tutoring guidance [28]. The learning constructs of students of prospective teacher offer constructive pedagogy, freedom, and courage to learn and foster meaning in digital literacy. This can respond the doubts about teacher professionalism in the future. It confirmed the previous studies that teachers' familiarity with digital media did not guarantee teachers' functional and pedagogical digital-based classroom learning. [1]. However, the learning will be easier if there are qualified teachers in the digital era [29]. 
Meanwhile, it can guarantee the academic and nonacademic improvement of prospective teachers, and reinforce previous studies if there are impressions of media use to literacy skills, including academic achievement [30]. This research can be a reference towards the development of learning technology in the New Normal era and give a concern towards the importance of different paradigms of inquiry, testing, and study contexts. However, empirical facts have supported that digital media was the last choice in learning during the Covid-19 Pandemic era.

\section{Conclusion}

The demand of digital media has call on that each individual should not reject anything related to learning issue. Although digital media has contributed much but its use should be adapted and constructed. Learning construct which is based on digital media literacy demand to be considered on students of prospective teacher as the professional entity in transforming learning so that it strengthens competence and social relation. Besides, it is expected that ideal students of prospective teacher are placed on the forefront of digital literacy movement because the activities they undertake are academic and a part of literacy activity. An excellent digital literacy media-based learning will support learning skill and professional prospective teachers in the future.

\section{References}

[1] M. Tzifopoulos, "In the shadow of Coronavirus: Distance education and digital literacy skills in Greece,” vol. 5, no. January, pp. 1-14, 2020.

[2] S. Gifary and I. Kurnia N, "Intensitas Penggunaan Smartphone dan Prilaku Komunikasi (Studi Pada Pengguna Smartphone di Kalangan Mahasiswa Program Studi Ilmu Komunikasi Universitas Telkom)," J. Sosioteknologi, vol. 14, no. 2, pp. 170-178, 2015, doi: 10.5614/sostek.itbj.2015.14.2.7.

[3] J. P. Sitorus, "Literasi Digital: Kontribusi Dan Tantangan Dalam Keterampilan Menulis," Alf. J. Bahasa, Sastra, dan Pembelajarannya, vol. 2, no. 2, pp. 75-85, 2019, doi: 10.33503/alfabeta.v2i2.612.

[4] L Nuraeni, R Purwasih, and J Mustakim, "IKIP Siliwangi student's perceptions of online teaching and learning process during Covid-19 pandemic ? IKIP Siliwangi student's perceptions o f online teaching and learning process during Covid-19 pandemic ?,” J. Phys. Conf. Ser., vol. 1657, no. 1, 2020, doi: 10.1088/1742-6596/1657/1/012084.

[5] B. Nadeak, "The Effectiveness of Distance Learning Using Social Media during the The Effectiveness of Distance Learning Using Social Media during the Pandemic Period of Covid-19: A Case in Universitas Kristen Indonesia,”Int. J. Adv. Sci. Technol., vol. 29, no. 7, pp. 1764-1772, 2020.

[6] M. Churiyah and D. A. Sakdiyyah, "International Journal of Multicultural and Multireligious Understanding Indonesia Education Readiness Conducting Distance Learning in Covid-19 Pandemic Situation," pp. 491-507, 2020.

[7] M. Yanti, "Determinan literasi digital mahasiswa: kasus Universitas Sriwijaya [Determinants of students digital literacy: the case of Sriwijaya University]," Bul. Pos dan Telekomun., vol. 14, no. 2, p. 79, 2016, doi: 10.17933/bpostel.2016.140202.

[8] R. Nasrullah et al., Materi Pendukung Literasi Digital: Gerakan Literasi Nasional. Jaka: Kementerian Pendidikan dan Kebudayaan, 2017.

[9] N. Pratiwi and N. Pritanova, "Pengaruh Literasi Digital Terhadap Psikologis Anak Dan Remaja," Semantik, vol. 6, no. 1, p. 11, 2017, doi: 10.22460/semantik.v6ilp11.250.

[10] L. Kervin, S. Danby, and J. Mantei, "A cautionary tale: digital resources in literacy classrooms," Learn. Media Technol., vol. 44, no. 4, pp. 443-456, 2019, doi: 10.1080/17439884.2019.1620769. 
[11] Lutviah. I.K., "Pengukuran Tingkat Literasi Media Berbasis Individual Competence Framework: Studi Kasus Mahasiswa UniversitasParamadina," 2011.

[12] O. Avidov-ungar and A. Forkosh-baruch, "Professional identity of teacher educators in the digital era in light of demands of pedagogical innovation," Teach. Teach. Educ., vol. 73, pp. 183-191, 2018, doi: $10.1016 /$ j.tate.2018.03.017.

[13] E. Tour, "Teachers' personal learning networks (PLNs): exploring the nature of self-initiated professional learning online," Literacy, vol. 51, pp. 11-18, 2017, doi: https://doi.org/10.1111/lit.12101.

[14] D. Puspito, Wahyu, "Implementasi Literasi Digital dalam Gerakan Literasi Sekolah.," 2017.

[15] T. Shopova, "Digital literacy of students and its improvement at the university," J. Effic. Responsib. Educ. Sci., vol. 7, no. 2, pp. 26-32, 2014, doi: 10.7160/eriesj.2014.070201.

[16] A. Sujana and D. Rachmatin, "Literasi digital abad 21 bagi mahasiswa PGSD: apa, mengapa, dan bagaimana," Current Research in Education: Conference Series Journa, vol. 1, no. 1, pp. 1-7, 2019, [Online]. Available: https://ejournal.upi.edu/index. php/crecs/article/view/14284.

[17] S. Talib, "Social media pedagogy: Applying an interdisciplinary approach to teach multimodal critical digital literacy," E-Learning Digit. Media, vol. 15, no. 2, pp. 55-66, 2018, doi: $10.1177 / 2042753018756904$

[18] Firdaus, H. Rahman, Umar, S. Ni’mah, and Harmilawati, “Conception of Religion Teacher in Bugis Makassar Cultural Context," vol. 436, pp. 960-965, 2020, doi: 10.2991/assehr.k.200529.201.

[19] A. Bandur, Penelitian Kualitatif Metodologi, Desain, dan Teknik Analisis Data dengan NVIVO 11 Plus. Jakarta, 2016.

[20] J. W. Creswell, Educational Research, Planning, Conductin and Evaluating Quantitative and Qualitative (Four Edition). Boston: Boston: Person, 2012.

[21] Miles Huberman \& Saldana, Qualitative Data Analysis A Methods Sourcebook (3 Edition). Arizona: SAGE Publications, Inc., 2014.

[22] L. Mishra, T. Gupta, and A. Shree, "Online Teaching-Learning in Higher Education during Lockdown Period," International Journal of Educational Research Open, p. 100012, 2020, doi: 10.1016/j.ijedro.2020.100012.

[23] B. Wei, "Covid-19 and online teaching in higher education A case study of Peking University" pp. 113-115, 2020, doi: 10.1002/hbe2.191.

[24] E. U. Hanik, "Self Directed Learning Berbasis Literasi Digital pada Masa Pandemi Covid-19 Di Madrasah Ibtidaiyah Elementary,” Islam. Teach. J., vol. 8, no. 1, pp. 183-208, 2020.

[25] R. Rastati, "Media Literasi Bagi Digital Natives: Perspektif Generasi Z Di Jakarta,” J. Kwangsan, vol. 6, no. 1, p. 60, 2018, doi: 10.31800/jtp.kw.v6n1.p60--73.

[26] [26] W. Zhang, Y. Wang, and L. Yang, "Suspending Classes Without Stopping Learning: China' s Education Emergency Management Policy in the Covid-19 Outbreak."

[27] S. N. Sailin and N. A. Mahmor, 'Improving Student Teachers' Digital Pedagogy Through Meaningful Learning Activities" vol. 15, no. 2, pp. 143-173, 2018.

[28] C. N. Dedebali, "Analysis of Digital Literacy and Metaphoric Perceptions of Teacher Candidate," Int. J. Educ. Methodol., vol. 6, no. 1, pp. 135-145, 2020, doi: 10.12973/ijem.6.1.135.

[29] R. Fanreza, "The Quality of Teachers in Digital Era," vol. 231, no. Amca, pp. 461-463, 2018.

[30] R. Syah, D. Darmawan, and A. Purnawan, "Analisis Faktor yang Mempengaruhi Kemampuan Literasi Digital,” J. Akrab, vol. 10, no. 2, pp. 60-69, 2019. 